\title{
THE CONSTITUTIONAL RATIONALIZATION OF THE SEPARATION OF POWERS: THE CASE OF SERBIA**
}

\begin{abstract}
The main goal of this paper is to analyze the modalities of the separation of powers in the constitutional state. The starting point is that "pure" forms of separation of powers no longer exist even in traditional constitutional states, whereas in the so-called new democracies the practice is focused on exploring ways of rationalizing the traditional form of parliamentarism. Hence, the semi-presidential system as a new form in the $20^{\text {th }}$ century is proving to be a new platform upon which new modalities of the separation of powers are being built. After considering the theoretical framework of semi-presidentialism, the author focuses on the constitutional approach in the process of selecting the organizational model of the separation of powers. The central topic is the constitutional construction of the separation of powers in Serbia since 1990 and its development through two normative constructions. The last part of the paper highlights, in particular, the prospective of the national separation of powers framework and the possible mechanism for balancing two branches of political power.
\end{abstract}

Keywords: Constitution of Serbia, Government, National Assembly, President of the Republic, semi-presidential system, separation of powers.

\footnotetext{
*irena@prafak.ni.ac.rs

** This paper is a result of research on the Project "The Protection of Human and Minority rights in the European Legal Area" (No. 179046), financially supported by the Ministry of Science of the Republic of Serbia.
} 


\section{Introduction}

A need to explore the possibility of modifying the traditional separation of powers has been evident in the contemporary constitutional state. The "pure" form of separation of powers from the liberal state can no longer give the same effect in the newly created political and social milieu. Hence, difficulties arise when we are trying to choose a constitutional model in so-called new democracies. The power and the role of political parties must be taken into account in modern times because they are the connective tissue of normative constitutional construction. However, according to Carl J. Friedrich "if constitutional law begins to ask what people do under particular constitution, and not merely what battle of words they engage in for the settlement of conflicts among them, the constitutional lawyer becomes a political scientist (one hopes)" (Rosenfeld, Sajó, 2012: 6). In this paper, risking that the principle of separation of powers may move away from interpretation with purely legal arguments, the Serbian constitutional model will be considered by taking into account the undeveloped political and parliamentary pattern that exists in the Republic of Serbia.

Since the beginning of the $20^{\text {th }}$ century, the liberal model of democracy has encountered economic and social challenges which disturbed the capitalist order and led to the emergence of new political choices. This historic milestone has shown that a pure parliamentary model is, with some exceptions, increasingly difficult to implement in its original form. At this stage of constitutional development, new elements have been introduced into the traditional scheme of the separation of powers in order to replace the center of gravity between the constitutional authorities: the legislature and the executive. If we compare this issue with the one at the beginning of the $20^{\text {th }}$ century, it could be said that the modern state based on the separation of powers also requires certain intervention and correction today. It would not be wrong to quote political thinkers from last century (Hugo Preuss, Max Weber and Carl Schmitt) who sought a way out of the parliamentary crisis and considered new forms of government as a modification of classical liberal theory. Thus, Max Weber changed his stance on the correction of parliamentary democracy from his original opinion in 1918, which promotes the liberal concept of balance in parliamentarism, to the latter view that the direct election of the head of state must be accepted as a "need" to prevent parliamentary crises. At that time of the great crisis, English parliamentarism was thought to be "real", but it did not correspond to the "critical" moment of Germany in the period after the First World War (Kennedy, 2000: xxiv). ${ }^{1}$ Also, the Parliament was seen as an authority with reduced function to

1 In this regard, Gustav Radbruch also appreciated the function of the President of the Weimar Republic: "If democracy and parliamentarism are to function, a scale of trust and increasing independence of action must be constructed from the voters in the country through their 
the level of a "show", with no real power to deal with non-parliamentary actors who wish to exert their influence and who do so successfully through political parties they are connected with. However, the light motive was not to encourage the citizens to get involved in politics. On the contrary, when the political game does not work, the divided society should be offered "the opportunity to elect its own powerful national symbol, a symbol standing above politics when politics became too messy", which was possible through the strong legitimation of one exponent of the executive, i.e. the head of state (Skach, 2007: 98).

The principle of the separation of powers is still the fundamental one in the modern constitutional state, but it has lost its original conceptual and political components. Hence, there is an opinion that this principle is getting old, especially because it is difficult to keep his organizational and functional balance. Due to the growing needs of the modern state, the power shifts to the hands of executive authorities which are able to perform numerous functions, unlike the cumbersome representative assembly. In addition, the phenomenon of the Constitutional Court at the beginning of the $20^{\text {th }}$ century generated theoretical reviews of the traditional separation of power and debates on the potential introduction of a fourth branch of power. Also, considering that numerous independent bodies and agencies carry out important tasks on behalf of the legislative and the executive authorities, a rethinking of the traditional principle is required. Although these modifications have come as a necessity in designing the government of a constitutional state, the problem is particularly emphasized when the principle is applied in states that have no experience with liberal democracy and the separation of powers.

\section{The possibility for constitutional approach}

In the modern age of the so-called new democracy, the constitutional choice ranges between three options: American, French and German. The American presidential system was impossible to apply in most new democracies under political conditions that form the framework for the constitutional organization of power. The traditional parliamentarism was taken with a reserve because

representatives all the way to the leading statesmen. Among these the Reichspräisident has a special place. ... The Reichspräsident is politically obliged to take appropriate measures if the government, which is responsible only to the parliamentary majority in the Reichstag, asks it of him... and to represent the republic with tact and dignity. ... Against the purely ceremonial interpretation of this office, another fact must be taken into consideration: that the constitution has given the Reichspräsident a fundamentally different political foundation from that of the Reich government based on the parliament, the important foundation of direct election by the people." (G. Radbruch, "Goldbilanz der Reichsverfassung," Die Gesellschaft 1 (1924), 65-66. Cited according to Kennedy, 2000: xxviii) 
it was mainly viewed through the parliamentary monarchy and rarely as the successful experiment of the parliamentary republic, which was the consequence of the possible parliamentary crisis. The constitutional choice, with more or less modifications, has been aimed at the French model of rationalized parliamentarism, also known as the semi-presidential system.

Following the collapse of real-socialism in Europe, a number of states adopted new constitutions establishing the separation of powers as a fundamental principle. In the short meantime, the academic debate focused mainly on the evaluation and effects of the parliamentary system traditionally applied in Western European countries. It was clear that the Presidential model in its original form was not applicable. ${ }^{2}$ Hence, the majority arguments went either "in favor of" or "against" the traditional parliamentary system, that is, for or against introducing rationalization into the level of a semi-presidential model.

Bruce Ackerman is one of the contemporary writers who think that choosing the American model is inappropriate for the new constitutional states. He also considers English parliamentarism, as a pure model under an unwritten constitution, an inappropriate form. Relying on the German mechanism of governmental organization, he thinks it should be the "constrained" parliamentarism (Ackerman, 2000: 641). According to him, the independently elected President of the Republic should not be recognized by the Constitution as a counterweight to the directly elected National Assembly. Instead, the Constitution should protect the Prime Minister and "his" Government as long as they enjoy the parliamentary majority support. The constrained parliamentarism has other mechanisms of "scrutiny", such as control by independent bodies and agencies through specific constitutional powers, including the Constitutional Court (Ackerman, 2000: 635-636).

Now, the question arises again: where are the limits of the extent to which it was possible to consistently derive the constitutional formula of the separation of powers under the specific political conditions in newly created systems? These conditions have not provided a good basis for the "political game", despite the view that the parliamentary system would be a safe and stable form in the process of establishing new democracies. The following has not provided a solid ground for the implementation of a pure parliamentary system: an under-built political system (numerous political parties, their fragile structure and somewhere the inherited communist model), a lack of experience with democratic

2 According to A. Lijphart (1991: 72), "two fundamental choices that confront architects of new democratic constitutions are those between plurality elections and proportional representation and between parliamentary and presidential forms of government". Looking at Latin American political systems, J. Linz (1990: 52) emphasized that parliamentarism is "more conducive to stable democracy" than presidentialism. (Also see: Lipset, 1990: 80-83; Horowitz, 1990: 73-79.) 
representation and direct elections, as well as a lack of functional capacity of the legislative and executive authorities. The Westminster democracy, as a political framework of English parliamentarism, has not been implemented, but other continental forms (types) have offered elements for discussion. ${ }^{3}$ Thus, mainly in Eastern European countries, as well as in those created in the former Soviet Union and Yugoslavia, considerable preference has been shown to the French constitutional model, both in academic and in political debates. ${ }^{4}$ There is an opinion suggesting that this system had mainly originated in the process of transition from the authoritarian to a democratic system, as was the case with states dominated by the socialist political system which was firmly and ideologically aligned with the constitutions of that time. ${ }^{5}$

The semi-presidential model has been created in post-socialist countries during the process of democratization at the same time as the process of parliamentarization (Beyme, 2000: 18-19). There is an opinion that the semi-presidential model with proportional representation has been a good compromise between new and old political elites, as well as that it could be "a functional equivalent of party control" with the purpose to avoid "the special interest" of the legislator (Beyme, 2000: 31). Also, the strong President could alleviate weakness of Parliament and the Government in newly created states (Siaroff, 2003: 288). Taking into account all conditions, the semi-presidential system is capable of combining two essential features: greater capacity to rule and greater institutional flexibility than parliamentary and presidential systems (Pasquino, 1997: 136).

The new model of separation of powers was classified in the 1980s by Maurice Duverger as "semi-presidential", which was defined not only as the simple synthesis of parliamentary and presidential types but as the authentic system in which parliamentary and presidential phases alternate (Duverger, 1980: 165-187). In circumstances where the directly elected head of state enjoys the support of a same majority sitting in Parliament and the support of the Government, there are assumptions for overriding features of the presidential government. In reverse, the system has the characteristics of a parliamentary government

3 It has been developing under the conditions of "unwritten constitution" and a two-party system that was not attainable in the so-cold new democracies. (Verney, 1994: 31-48)

4 In addition to new European countries, this system has been implemented in many countries in Asia, Africa and Latin America. In countries that are abandoning the presidential system or at least resisting the influence of this model, G.Sartori (1994: 135-136) believes that a wiser choice is a semi-presidential system, because parliamentarism would be a leap into something different and unknown. Also see Elgie (ed.) 1999; Skach, 2005: 1-2.

5 In addition, the crisis of parliamentarism is a possible cause for the transition to a semipresidential model, as in the case of the removal of the Fourth French Republic (Pasquino. 1997: 136). 
when the Government comes from a parliamentary majority opposed to the President of the Republic. Since this theoretical classification, various subtypes of this model of separation of power have evolved to this day. ${ }^{6}$ The tertius genus model is confirmed by the fact that the number of so-called semi-presidential systems has increased. The share of this form of government has jumped from $22 \%$ in the 1990 s to $33 \%$ in 2007 (in the wake of the new constitutions of the North Africa and the Middle East countries). ${ }^{7}$ The rise of the "third" model could also lie in the fact that variations or subtypes of the semi-presidential system have begun to develop rapidly in the modern process of constitutionalization.

Differentia specifica of the semi-presidential model can be found in the following: two different political majorities have the same legitimate source; the directly elected head of state has the ability to "relieve the pressure on parliament to form majorities capable of producing decisions" and he has "strong institutional incentives to inhibit the parliamentary ability to organize a majority" (Möllers, 2013: 112-113). However, there could be found a hidden intent: the head of state with strong institutional capacity can disable a parliament to form majority which leads to the following situation: "the weaker the parliament is, the stronger the president becomes" (Möllers, 2013: 113). Hence, there is an assumption that the head of state can use his competence to dissolve the Parliament in order to destabilize the parliamentary and legislative process. As a consequence, there is an opinion that in the semi-presidential system, unlike the pure presidential model, there will be no two parallel structures of power, but only one of them will remain in the end. Also, unlike in traditional parliamentarism, the Government is less dependent on Parliament; instead, Parliament is largely dependent on the head of state.

Another argument can be made in favor of choosing a semi-presidential model, although it stands on the thin edge of being a counterargument, which is

6 It is worth mentioning the new classification of Shugart and Carey: presidentparliamentary and premier-presidential (Shugart, Carey, 2003: 269).

7 According to R.Elgie, countries with a semi-presidential constitution (as of December 2010) are: Algeria (1989), Guinea-Bissau (1993), Russia (1993), Armenia (1995), Haiti (1987), Rwanda (2003), Austria (1945), Iceland (1944), Săo Tomé e Príncipe (1990), Azerbaijan (1995), Ireland (1937), Senegal (1991), Belarus (1996), Kazakhstan (1993), Serbia (2006), Bulgaria (1991), Kyrgyzstan (1993), Slovakia (1999), Burkina Faso (1991), Lithuania (1992), Slovenia (1992), Cameroon (1991), Macedonia (1991), Sri Lanka (1976), Cape Verde (1990), Mali (1992), Taiwan (1996), Central African Republic (2005), Mauritania (2009), Tanzania (1995), Chad (1996), Mongolia (1992), Timor-Leste (2002), Congo-Kinshasa (2006), Montenegro (2006), Togo (1992), Croatia (1991), Mozambique (1990), Tunisia (1988), Egypt (2007), Namibia (1990), Turkey (2007), Finland (1919), Peru (1993), Ukraine (1996), France (1962), Poland (1990), Yemen (1994), Gabon (1991), Portugal (1976), Georgia (2004), Romania (1990). (Elgie, 2011: 24) 
considered to be a consequence of applying this model. The point is that prime ministers in most Eastern European countries have weaker authority than the heads of state, and they are unable to carry out a single term (mandate) in continuity. This can be interpreted as a consequence of the directly elected President of the Republic. Hence, this would be an argument in favor of the parliamentary system in which the Government and the parliamentary majority would be given a chance to assume their position in the separation of powers. On the contrary, the prime ministers of Western European countries are "strong" personalities; they can control the parliamentary majority and their reputation is seen as a necessary support and condition for the political party's success. In the new democracies, however, prime ministers do not have the capacity to stay in power for a long time; according to Thomas A. Baylis (2007: 82), they have "rarely remained in office long enough to solidify his authority, much less to dominate his nation's politics".

From the constitutional point of view, the problem of defining a semi-presidential model lies in the fact that it is not enough to analyze the normative/constitutional framework, but there is a need to consider the political reality on the same issue. If the head of state does not (miss)use his/her competences to strike a balance between the Parliament and the Government, then the semi-presidentialism maintains its values. Vice versa, if the constitutional powers of the head of state are used for political arbitration purposes, even in the pure parliamentary system, then constitutional construction can collapse. According to C. Skach, "at least from the perspective of democracy, presidents who take advantage of this constitutionalized autonomy for an extended period transform their countries from semi-presidential democracies into constitutional dictatorships" (Skach, 2007: 98).

\section{The organizational structure in Serbian constitutions since 1990}

Along with the fall of the Berlin Wall, the tragic dissolution of the Yugoslav Federation began at the beginning of 1990s. All Federal Republics, later independent states, adopted their own constitutions. The adoption of the Constitution of the Republic of Serbia in 1990 was supposed to institute the system based on the principle of the separation of powers with certain instruments for balancing it. The institutionalization of the separation of powers in Serbia from 1990 until the adoption of the Constitution 2006 went through two stages that marked its development.

The period from 1990 to 2000 was known as Miloševićs rule (the same adjective was also assigned to the Constitution), during which an implementation of the constitutional principles was proceeding under "bad" conditions: the use of an 
armed conflict to preserve the Yugoslav Federation (the two-member Federation remained from 1992), the multy- and under-developed party system (without federal political parties), an inherited political structure with the authoritarian rule. However, the organizational construction in the formal sense was semipresidential. The political majority limited, to say the least, the separation of powers in order to transfer the focus of power to the President of the Republic. The strong political influence of the head of state with his personal authority was moving towards weakening the institutional capacity of other constitutional bodies, primarily the National Assembly. In the first decade, there was (more or less) a complete political consensus in terms of relations between the National Assembly, the Government, and the President of the Republic, which further influenced the strengthening of the President's constitutional and political position. When at one point (in 1993) this political consensus ceased to function and the Government lost the support of the parliamentary majority, ${ }^{8}$ the President decided to exercise his role of "constitutional arbiter" through his competence to dissolve the National Assembly. Thus, the possibility of cohabitation was eliminated and parliamentary elections supplied the President with a political majority; throughout this period, Prime Ministers were weak and "disposable".

The second period of time (from 2000 to 2006) took place under the same legal framework, but with the new "political" constitution: elections at all levels and victory of the opposition coalition that introduced the new democratic Government (Prime Minister Zoran Djindjić and President of the Federal Republic of Yugoslavia Vojislav Kostunica). After 2000, the institutional construction moved towards the parliamentary system with a high level of rationalization, but these elements of rationalization developed on the other hand: between the National Assembly and the Government. If we accept M. Duverger`s definition that the semi-presidential Republic is, in fact, an alternative to or replacement of the presidential and parliamentary phases, ${ }^{9}$ it means that in the first years

8 After the early parliamentary elections in 1992, the Government was formed by "a homogeneous political minority" which concurrently supported the President of the Republic. The Government was formed by one political group (SPS) in the National Assembly (101 deputies), but with the consent of the second most powerful political group (SRS with 73 deputies). When the "tacit" agreement failed and the issue of trust in the Government was raised, the President of the Republic used his constitutional authority and dissolved the parliament.

9 According to A.Lijphart, "the strength of Duverger's 1980 analysis is also shown by its predictive ability". Namely, Duverger "dictates not a half-presidential and half-parliamentary form, but alternating presidential and parliamentary phases: presidentialism as long as the presidency and the parliamentary majority belong to the same party or coalition, and parliamentarism when they are in the hands of opposing parties or coalitions." (Lijphart, 1997: 127) 
of the second period (2000-2003) Serbia had predominant features of the parliamentary system.

After the parliamentary elections 2003 and the presidential election 2004, it was for the first time that the system began operating under conditions of the "peaceful" cohabitation. This stage predominantly had the characteristics of the premier-presidential form of government because a sort of peaceful cohabitation agreement was reached between the two political majorities, the President and the Prime Minister. With the equal legitimacy source these two constitutional authorities exercised their constitutional powers by protecting an institutional capacity of the National Assembly. The President of the Republic used his right of a suspensive veto, but the Government retained dominance in the legislative process in terms of the number of submitted and adopted legislative proposals. In addition, the President was mainly engaged in foreign policy affairs, while the Prime Minister and his cabinet were performing internal policy affairs. The consensus reached between the parliamentary majority and the parliamentary minority on the adoption of the new Constitution 2006 provided a good basis for ending the first successful cohabitation in the Serbian constitutional system.

After the adoption of the new Serbian Constitution in 2006, the organizational structure of the state in the formal sense remained largely identical to the previous one. The relationship between the legislature and the executive, as well as a correlation within the executive authorities, indicate that the main focus of the separation of powers is highly rationalized in the direction of the semi-presidential model. The Government is subject to formal investiture in the National Assembly at the proposal of the head of state and it is accountable through the ministerial responsibility, individual and collective. On the other hand, the President of the Republic is directly elected by the citizens and he, in addition to the traditional ones, also possesses those constitutional powers that can be a powerful instrument, but only when the "political" constitution provides the conditions for exercising these powers. Thus, the suspensive veto does not automatically is not applicable because the National Assembly decides whether to put the same issue on the agenda, while the power to dissolve parliament can only be exercised by the President of the Republic "upon an elaborated proposal by the Government". Although formally these powers appear to be "restricted", they can be used as controlling instruments in the system of separation of powers if the directly elected head of state has "his own" political majority in Parliament and, on the same basis, "his" Government. This shift of focus from the legislative to the executive authority in the constitutional system of Serbia has taken on the characteristics of a semi-presidential system, because it must be taken into account that the formal constitutional framework is subject to the 
corresponding dynamics of the so-called political constitution. ${ }^{10}$ The author of this paper is inclined to believe that this is a sort of semi-presidential system in the formal sense, ${ }^{11}$ but under certain political conditions and behavior of government officials, it becomes a type of "constitutional dictatorship". This "form" has been developed in the current President's term of office, beginning from the presidential election in 2017. The head of state, who is at the same time the head of the strongest political and parliamentary party, takes over all the activities of the executive authority (although formal acts are signed by disposable "single-use" ministers); thus, the Government becomes a service without action and influence. ${ }^{12}$ This situation is directly reflected in the National Assembly, which has been exhausted in supporting the political action of the head of state, and thus loses even the little influence that citizens expect from a representative body. So, if the head of state exercises its political power with strong personal authority (such as in Serbia), a completely distorted mirror of semi-presidentialism is created and the Constitution becomes merely a cover for a "false" separation of powers. Although we are only dealing here with the political authorities, such "usurpation" of powers undermines the concept of the rule of law because it directly affects the independent judiciary. In fact, in-

10 There are different views in the national literature about the nature of constitutional organization of powers. Thus, during the 1990 Constitution, such a shift of focus, in the opinion of P. Nikolić (1991: 91), indicated one (by its construction) mixed and quasi-parliamentary system in Serbia, while M. Jovičić (1992: 34) believed that the system could be classified in the semi-presidential group. After the adoption of the 2006 Constitution, authors also had their own views on it. Thus, R.Marković (2008: 208) believes that the system "has the external characteristics of a mixed system" but, considering the limited powers of the President of the Republic to appoint and dismiss the Prime Minister, the system "tends to be more parliamentary than a mixed system", i.e. it tends to "streamline the parliamentary system". D.Simović (2008: 316) believes the 2006 Constitution weakened the position of the President of the Republic and strengthened the position of the Government, and "it is unambiguous from the whole of the constitutional solutions that the Government is the only effective and operational part of the executive". According to S.P.Orlović (2016: 1211), the President of the Republic should not be "party-involved". If this constitutional function is connected with party-involved function, the constitutional organization of powers is deformed.

11 Until recently, the classification of Serbia's constitutional model has not appeared in comparative literature. It could be said that Milosevic's rule was not suitable for classification; thus, the Serbian Constitution of 1990 was not taken as the basis for the classification of the national model. In one of the recent classifications given in the monograph study by $\mathrm{R}$. Elgie (2012: 24), Serbia is listed as one of the 20 post-communist countries implementing the semi-presidential system.

12 It is possible to compare this situation with the early beginning of the Fifth French Republic when, according to C. Skach, there was "one clearly observable symptom of constitutional dictatorship" embodied in the president's "packing the cabinet with non-party colleagues rather than with representatives from the political parties" (Skach, 2007: 98). This is precisely the case with the Prime Minister in Serbia. 
dependent judicial bodies (the High Court of Justice and the State Prosecutors Council) are elected by the National Assembly, which is then reflected in the process of appointing judges and prosecutors. The latter is not only a hallmark of the most recent time but it has also been a flaw in all legislatures since 2006.

\section{Prospective national construction of the separation of powers}

The main issue we are facing now is: whether the future constitutional change can bring the pendulum back into balance and enable the establishment of a parliamentary Government with a stable Prime Minister as a political leader, or put differently, whether the existing formal framework should be preserved in anticipation that in the future there will be an opportunity for alternating presidential and parliamentary phases without an authority overrun. It is difficult to give an answer to this question which would completely satisfy the goals of the separation of powers, since it is almost impossible to consistently defend one model without neglecting political parties' rules and a projection of their forces in the future (Pejić, 2016: 67-85). In addition to looking at potential solutions through their formal expression, it is necessary to consider the possibilities of a "living" constitution and political "game" that can be developed under the same formal normative framework. The meaning of "political rules" in new democracies is not the same as in Western European countries ${ }^{13}$ because they are "fresh" and have fluid forms with changeable participants in the political process (considering the pronounced tendency to choose leaders who can "create and break" rules on their own).

Given that both models of profiling the head of state, the "parliamentary" and the "plebiscitary" President of the Republic, can be found in European constitutions, pleading for one of them should be based on arguments about the institutional strength and the need for stability of the separation of powers in Serbia. If we consider the existing circumstances in the national system pertaining to the relationship between the two branches of political power, the legislative authority has been more exposed to erosion of its functional power than it has been the case with the executive authorities. This is supported by the absolute dominance of the Government in the process of drafting the law, whereby the National Assembly has not used constitutional competences to strengthen its own position as a representative and legislative authority. Not only did the government's bills far exceed the legislative initiative of the deputies, but the Parliament did

13 Karl von Beyme (2018: 41) opens a new view on Eastern European democracies as "defective democracies", in which danger arises "because the tradition of a sufficiently established party system has not yet evolved". In addition to Romania and Slovakia, Serbia is a country where "the fluctuation of electors to which populist groups contribute threatens to contribute to unstable party systems". 
not put on the agenda the initiatives that came directly from the citizens (the national initiative). Thus, the parliamentary majorities in all legislatures thus far have made themselves completely dependent on governmental bills, as well as on the executive action in general (and on the Presidential action in particular). The parliamentary majority in the National Assembly has behaved "submissively" towards the executive authority and it has respected, without reservation, the Government's proposals for implementing urgent law-making procedures (reducing the time for discussion in the plenum and limiting the participation of the parliamentary minority). This has compromised the parliamentary structure and its power in two ways: firstly, by weakening the parliamentary opposition and, second, by weakening the individual position of parliamentarians (MPs). Consequently, a contextual legitimation of the National Assembly is gradually decreasing due to the continued neglect of the parliamentary minority. There has been no attempt to establish "the opposition days" or days reserved for minority bills, which may serve as a kind of "vent pipe" and an opportunity to hear "a second opinion", especially in favor of strengthening the functional capacity of Parliament in relation to the Government.

On the other hand, the dominance of the Government in the legislative process is obvious and, in a way, it is implied in the rationalized parliamentary system. The main problem here is about exercising a function of the "real" chief executive: is it the Prime Minister or the President of the Republic? The next question is also whether it is possible to establish a parliamentary balance when the representative body has a monocameral structure. The bicameral assembly is a good "proofreader" in the relationship between the Parliament and the Government; it is an opportunity for "a second opinion" of the other house with the capacity to reduce an executive political influence and ensure stability within the legislative authority with an aim of pursuing legislative policy. The bicameral structure of Parliament could protect the legislative functional capacity since the Government cannot dominate, through its proposals and powers, at all stages of the legislative procedure. Therefore, changing the structure of parliament could be one of the factors for balancing power in the "plebiscitary" President system. Thus, the constitutional construction including the bicameral Parliament, the Government, and the "plebiscitary" President could meet the needs of the separation of powers in the theoretical point of view. However, from the political point of view this institutional construction could be dangerous: the second house can be a nucleus for the "plebiscitary" President domination if the lower house would be won by the opposition.

The second possible change in the constitutional construction would be the introduction of the "parliamentary" President with the aim of minimizing the consequences of rationalizing parliamentarism and balancing the separation 
of powers. The head of state could be elected by Parliament and he would not necessarily be the leader of the strongest political party. In this way, he can be "a neutral arbiter", leaving it to the Government to fully exercise its supremacy of political action. If the National Assembly remains in its monocameral form, there is a possibility to provide dual-structure representation within it. More precisely, the electoral system might ensure a "duality" in the representation if half of MPs are elected on a proportional basis and the other half on the basis of the majority system. In addition to the programmatic representation, the_personal choice election should be introduced as an opportunity for balancing the separation of powers through an alternative form of representation. It should not necessarily be the purely territorial representation, but it could provide a chance for expressing other opinions which are not automatically politically disciplined and forced. Therefore, the relationship between the monocameral National Assembly, the Government and the "parliamentary" President would be appropriate for the constitutional construction in Serbia.

When it comes to the responsibility of the two constitutional branches, in addition to their accountability before the citizens as the original source of constitutional power, it is important to introduce the concept of legal responsibility (liability) of the head of state in the construction of the "plebiscitary" President. In this respect, the current Constitution of Serbia has an inconsistent model, indicating that the President of the Republic is accountable for "the violation of the Constitution" to the National Assembly although, under the Constitution, it is the Constitutional Court that is vested with the authority to adjudicate in liability-related proceedings. However, as the final decision is made by a twothirds parliamentary majority, then it can be reasonably said that the political responsibility of the President of the Republic has been (covertly) introduced through "the back door". Therefore, it is important to return this aspect of the separation of powers to the legal meaning of this principle; to this effect, the Constitutional Court or the Supreme Court in the state should be obliged to decide on the legal responsibility (criminal liability) of the head of state.

\section{Conclusion}

Considering the constitutional period since the adoption of the 1990 Constitution and the subsequent adoption of the 2006 Constitution of the independent Republic of Serbia until the present, it can be said that the state has gone through several phases. In a relatively short time, we had two constitutions and experienced several political transformations in the system of separation of powers, which basically retained the hallmarks of semi-presidentialism. Although drawing a line and making substantiated conclusion requires a longer constitutional 
and political experience, it is possible to make a cross-section of what has been achieved and present some solutions for prospective constitutional changes. The starting point should be sought in the mechanism (or mode) for balancing the separation of powers, which should have a "safety valve" to overcome potential conflicts between different political majorities. When tension in political power relations escalates, one should use the "express pot" safety mechanism and find an authority which has legitimacy to give a "second opinion". In the traditional parliamentary system, this mechanism can be found in the so-called "parliamentary" head of state as a neutral arbiter in the political sense.

On the other hand, the so-called "plebiscitary" President cannot be a neutral arbiter in the political framework of rationalized parliamentarism. With the dominant Government and the powerful head of state, there is a real danger that the National Assembly will be completely stifled "in the arms" of the executive authority. The constitutional reality in Serbia is such that it has not been possible thus far to clearly identify the institutional powerholders, but only the personal holders of power. Thus, for example, the institutional position of the National Assembly has heavily depended on the politicians in the position of the Prime Minister or the head of state, involving an open process of personalizing power. The "personalization" of power can be understood in two ways: firstly, as the danger of overruling and usurping power, and secondly, as "creeping" instrumentalization of constitutional mechanisms by an exponent of the executive power who embodies the personal authority and the power of a political party.

Therefore, it is important to think about restoring the power to the National Assembly, which can be done potentially through a bicameral or dual-structure and by envisaging instruments for its functional strengthening. A bicameral or dual-structure would open up the possibility of mitigating programmatic or political representation and introduce territorial or functional representation, which would provide a "second house" opinion. In a situation where the head of state uses his powers excessively, suppressing the National Assembly and the Government with absolute personal and political authority, the solution may be found in obtaining a "second opinion" of the majority supported by the citizens, which does not necessarily have to be party-oriented. Also, the process of distancing from the executive branch may include resorting to the Constitution (constitutional provisions) and strengthening direct democracy by instituting a referendum and by placing mandatory popular/citizen initiatives on the parliamentary agenda. The urgent legislative procedure, which is favored by the Government despite its clear dominance among the parliamentary majority, should be limited. Finally, it is necessary to establish the so-called "opposition days", when the parliamentary minority MPs would be able to present their proposals and bills that may later be discussed in the plenary session. 


\section{References}

Ackerman, B. (2000). "New Separation of Powers", Harvard Law Review, vol. 113. no. 3. 633-729.

Baylis, T.A. (2007). "Embattled executives: Prime-ministerial weakness in East Central Europe". Communist and Post-Communist Studies. no. 40. 81-106.

Beyme, K.v. (2000). Parliamentary Democracy: Democratization, Destabilization, Reconsolidation, 1789-1999. Palgrave Macmillan. London.

Beyme, K.v. (2018). From Post-democracy to Neo-Democracy. Springer International Publishing.

Duverger, M. (1980). "A New Political System Model: Semi-Presidential Government", European Journal of Political Research. vol. 8. no. 2. 165-187.

Elgie, R. ed. (1999). Semi-presidentialism in Europe. Oxford University Press.

Elgie, R. (2012). Semi-Presidentialism: Sub-Types and Democratic Performance. Oxford University Press.

Horowitz, Donald L. (1990). "Presidents vs. Parliaments: Comparing Democratic Systems". Journal of Democracy. vol. 1. no. 4. 73-79.

Jovičić, M. (1992). „Parlamentarni sistem nasuprot predsedničkom i skupštinskom sistemu", Arhiv za pravne i društvene nauke. no. 1. 29-49.

Kennedy, E. (2000). "Introduction: Carl Schmitt's Parlamentarismus in its Historical Context". In Carl Schmitt, The Crisis of Parliamentary Democracy. Cambridge, Massachusetts and London: Mit Press.

Lijphart, A. (1991). "Constitutional Choices for New Democracies", Journal of Democracy, vol. 2. no. 1. 72-84.

Lijphart, A. (1997). “Nomination: Trichotomy or dichotomy?". European Journal of Political Research. no. 31. 125-146.

Linz, Juan J. (1990). "The Perils of Presidentialism”. Journal of Democracy, vol. 1. no. 1. 51-69.

Lipset, Seymour M. (1990). "Presidents vs. Parliaments: The Centrality of Political Culture". Journal of Democracy. vol. 1. no. 4. 80-83.

Marković, R. (2008). Ustavno pravo i političke institucije, Beograd: Službeni glasnik.

Möllers, C. (2013). The Three Branches, a Comparative Model of Separation of Powers, Oxford University Press. 
Nikolić, P. (1991). „Ustav Srbije i problemi demokratizacije“, Pravni život, no. 1-2. 92-105

Orlović, S.P. (2016). “Šef države u Srbiji - kralj naspram predsednika republike”, Zbornik radova Pravnog fakulteta u Novom Sadu, no. 4. 1197-1212.

Pasquino, G. (1997). "Semi-presidentialism: A political model at work". European Journal of Political Research. no. 35. 128-137.

Pejić, I. (2016). „Parlamentarna vlada - mogućnosti ravnoteže u sistemu podele vlasti“. Zbornik radova Pravnog fakulteta u Nišu. no. 73. 67-85.

Rosenfeld, M., Sajó A. (Eds.). (2012). The Oxford Handbook of Comparative Constitutional Law. Oxford University Press.

Sartori, G. (1994). Comparative Constitutional Engineering: An Inquiry into Structures, Incentives and Outcomes. New York: Springer.

Schmitt, C. (2000). The Crisis of Parliamentary Democracy. (translated by Ellen Kennedy). Cambridge, Massachusetts and London: Mit Press.

Shugart, M.S., Carey J.M. (2003). Presidents and Assemblies. Cambridge University Press.

Siaroff, A. (2003). "Comparative presidencies: The inadequacy of the presidential, semi-presidential and parliamentary distinction", European Journal of Political Research. no. 42. 287-312.

Simović, D. (2008). Polupredsednički sistem, Beograd: Službeni glasnik.

Skach, C. (2005). Borrowing Constitutional Designs: Constitutional Law in Weimar Germany and the French Fifth Republic. Princeton and Oxford: Princeton University Press.

Skach, C. (2007). „The " newest " separation of powers: Semi-presidentialism“. International Journal of Constitutional Law. vol. 5. no. 1. 93-121.

Verney, D.V. (1994). "Parliamentary Government and Presidential Government". In A.Lijphart (ed.). Parliamentary versus Presidential Government. Oxford University Press. 31-48.

Wiberg, M. (1995). "Parliamentary Questioning: Control by Communication?", in: H.Döring (ed.) Parliaments and Majority Rule in Western Europe. Mannheim: Centre for European Social Research. 


\title{
Др Ирена Пејић,
}

Редовни професор Правног факултета,

Универзитет у Нишу

\section{УСТАВНА РАЦИОНАЛИЗАЦИЈА ПОДЕЛЕ ВЛАСТИ - НА ПРИМЕРУ СРБИЈЕ}

\begin{abstract}
Резиме
Упркос томе што је променио своју изворну идејну и политичку компоненту, принцип поделе власти остао је фундаментални принцип модерне уставне државе мада има мишљења да је овај принцип „остарио“. Након слома реалсоцијализма у Европи велики број бивших социјалистичких земаља донео је нове уставе којима је успостављен систем организације власти заснован на подели власти као темељном принципу правне државе. Бројне академске расправе, које су уследиле у кратком временском интервалу до доношења нових конститутивних аката, биле су усмерене претежно на оцену „ефеката“ парламентарног система. Међутим, највећи број нових устава определио се за трећи модел, тј. полупредседнички тип који је у процесу демократизације постсоцијалистичких земаља развијао своје особености паралелно са процесом парламентаризације. Има мишљења да је полупредседнички систем у комбинацији са пропорционалним изборима у новим системима био добар компромис између „нових и старих“ политичких елита.
\end{abstract}

Разматрајући кратку уставну историју Србије од доношења грађанског устава Републике 1990. године, а потом и Устава прве самосталне Републике 2006. године, могло би се рећи да је држава прошла кроз неколико фаза. У релативно кратком раздобљу добили смо два уставна формата и неколико политичких трансформација у систему поделе власти што се одразило на релну позицију шефа државе који је од почетка био профилисан као "плебисцитарни председник". Дакле, у уставном аранжману поделе власти учињена је значајна рационализација парламентаризма у корист егзекутиве, што је настало као последица низа друштвених, политичких, економских и социјалних захтева, упркос одсуству искуства са савременом формом поделе власт.

Питање пред којим се сада налазимо јесте: да ли је потребно мењати уставни оквир организације власти који би вратио клатно у оквире равнотеже парламентаризма јачањем владе и њеног председника у функцији „политичког вође" егзекутиве или треба очувати формални оквир који и надаље пружа могућности за политичку алтернацију „моћи“ унутар извршне власти између председника Републике и председника Владе. С обзиром да су оба модела 
профилисања функције шефа државе , парламентарни“ и „плебисцитарни председник", нашла своје утемељење у европским уставима, пледирање за један од њих требало би засновати на аргументацији о институционалној снази и потреби стабилности уставне власти. Политичка реалност у Србији је таква да се до сада нису могли јасно утврдити институционални, већ само персонални носиоци власти. Тако је институционална позищија Народне скупштине у великој мери зависила од чланова и председника Владе или од непосредно изабраног шефа државе, уз отворену опасност персонализације власти и прерастања у “уставну диктатуру". Отуда је вазно размисљати о успостављању јаког народног представништва у лику Народне скупштине, што може бити уцињено најпре кроз њену “бикамерализацију" и увођење дома за "друго мишљење", а потом и кроз инструменте за њено функционално јачање (преко снажења облика непосредне демократије, успостављања тзв. опозиционих дана и јачањем индивидуалне позиције народних представника). Дакле, уз задржавање форме "плебисцитарног председника" неопходно је унети бикамералну структуру парламента, која би могла да стабилизује односе како унутар легислативе, тако и у односу према егзекутиви.

Кључне речи: Устав Републике Србије, Влада, Народна скупштина, Председник Републике, полупредседнички систем, подела власти. 